\title{
Sesja naukowa dla uczczenia śp. ks. prof. Jerzego Chmiela (1935-2016), Kraków, 23 marca 2017
}

ks. Stanisław Wronka

Uniwersytet Papieski Jana Pawła II w Krakowie

stanislaw.wronka@upjp2.edu.pl (D) https://orcid.org/0000-0003-1582-8540

Bibliści Uniwersytetu Papieskiego Jana Pawła II w Krakowie, który jest spadkobiercą Wydziału Teologicznego Uniwersytetu Jagiellońskiego i Papieskiej Akademii Teologicznej, zorganizowali specjalną sesję poświęconą pamięci ks. doc. dra hab. Jerzego Chmiela, który odszedł do Pana 6 sierpnia 2016. Był on najpierw studentem teologii, a później wykładowcą Pisma Świętego na tej uczelni przez ponad czterdzieści lat. Spotkanie odbyło się do południa 23 marca 2017 w budynku Uniwersytetu Papieskiego przy ul. Bernardyńskiej 3 w Krakowie.

Rozpoczęła je msza święta o godzinie 9 w kaplicy, której pod nieobecność bpa Romana Pindla, ordynariusza Diecezji Bielsko-Żywieckiej, przewodniczył ks. dr hab. Stanisław Wronka, wykładowca Uniwersytetu Papieskiego Jana Pawła II w Krakowie i redaktor naczelny „Ruchu Biblijnego i Liturgicznego”. Była ona dziękczynieniem Bogu za życie i dzieło ks. Jerzego Chmiela oraz prośbą o jego zbawienie i o kontynuację jego dokonań dla dobra uczelni, środowiska biblijnego i wszystkich zainteresowanych Pismem Świętym. W homilii ks. prof. dr hab. Stanisław Hałas, dyrektor Instytutu Nauk Biblijnych, przypomniał podstawowe etapy drogi naukowej ks. Jerzego Chmiela, która rozpoczęła się na Uniwersytecie Jagiellońskim w Krakowie, przebiegała przez Papieski Uniwersytet Gregoriański i Papieski Instytut Biblijny w Rzymie i realizowała się aż do końca przede wszystkim na Wydziale Teologicznym w Krakowie.

Obrady zgromadziły sporo uczestników, głównie wykładowców i studentów Uniwersytetu Papieskiego. Na początku wszystkich uczestników 
powitał ks. prof. dr hab. Wojciech Zyzak, rektor uniwersytetu. Wyraził wdzięczność za zorganizowanie tej sesji poświęconej człowiekowi, dla którego uczelnia była wszystkim. Z nią związał swoje życie, dla niej angażował siły fizyczne i intelektualne, a także środki materialne. Życzył owocnego spotkania oraz by utrwaliło ono na długi czas pamięć o ks. Jerzym Chmielu i przyniosło nowe impulsy do kontynuacji rozpoczętych przez niego badań.

Pierwsza część sesji została zatytułowana Wkład ks. prof. Jerzego Chmiela $w$ biblistykę, a przewodniczył jej ks. prof. Stanisław Hałas. Jako pierwszy zabrał głos ks. prof. dr hab. Waldemar Chrostowski (Uniwersytet Kardynała Stefana Wyszyńskiego w Warszawie). Mówił o wkładzie ks. prof. Jerzego Chmiela w hermeneutykę biblijną. Już od końca lat sześćdziesiątych biblista krakowski zwracał uwagę na konieczność podejścia synchronicznego do Pisma Świętego, gdyż mająca charakter diachroniczny metoda historyczno-krytyczna nie docierała do aktualnego sensu tekstu jako całości. Jego intuicja znalazła potwierdzenie w dokumencie Papieskiej Komisji Biblijnej z 1993 roku pt. Interpretacja Biblii w Kościele. Prelegent wyznał, że to głównie dzięki ks. Jerzemu Chmielowi poznawał nowe trendy w biblistyce. Dr Zdzisław Kapera (Uniwersytet Jagielloński w Krakowie) wygłosił referat Ks. prof. Chmiel a badania Qumran. Był on podobnie jak ks. Chmiel uczniem ks. Aleksego Klawka. Podkreślił, że ks. Jerzy Chmiel interesował się żywo odkryciami w Qumran, informował o nich i wyrażał w artykułach i wystąpieniach swoje opinie, zwłaszcza w odniesieniu do małego skrawka papirusu 7Q5, który według niektórych badaczy miał stanowić fragment Ewangelii Marka. Ks. Jerzy Chmiel sugerował zbadanie na nowo groty 7, ale niestety nie zdążono tego zrobić przed jej osunięciem się. Współpracował też z prelegentem przy organizacji kongresów qumranologicznych i publikacji prac poświęconych tej tematyce.

Po przerwie wystąpił ks. dr hab. Stanisław Wronka, który mówił na temat Ks. prof. Jerzy Chmiel jako redaktor „Ruchu Biblijnego i Liturgicznego”. Zreferował pokrótce publikacje ks. Jerzego Chmiela w czasopiśmie, które obejmują lata 1962-2004 i liczą prawie 300 pozycji. Były to zazwyczaj krótkie formy, w których stał się mistrzem. Mówca przeszedł potem do prezentacji pracy ks. Jerzego Chmiela w funkcji 
sekretarza redakcji (1970-1978), członka redakcji (1979-1981), redaktora naczelnego (1982-2007) i znów członka redakcji (2008-2015) „Ruchu Biblijnego i Liturgicznego”. Ks. Jerzy Chmiel na łamach czasopisma informował o tym, co działo się wokół Biblii w Polsce i za granicą - o tłumaczeniach, badaniach, spotkaniach, wydawnictwach. Jak mówił, w poczynaniach redakcji musi być coś z tytułowego „ruchu”. Nie zaniedbywał przy tym aspektów duszpasterskich, obecnych w czasopiśmie od samego początku. Z powodu nieobecności dr. Przemysława Deca (Uniwersytet Jagielloński w Krakowie), który miał mówić na temat Ks. prof. Jerzy Chmiel i językoznawcze badania starożytnych tekstów hebrajskich w kontekście naszej wspótpracy, swój referat Problematyka wiary $w$ Liście do Galatów w perspektywie wspomnień współpracy z Promotorem przedstawił ks. dr Ryszard Kempiak SDB (Papieski Wydział Teologiczny we Wrocławiu). Podzielił się doświadczeniem ciekawej współpracy z ks. Jerzym Chmielem przy doktoracie, a następnie przedstawił główne tezy swej dysertacji dotyczącej wiary tak istotnej dla usprawiedliwienia i zbawienia człowieka.

Na drugą część, którą poprowadził ks. dr hab. Roman Bogacz, prof. UPJPII i prodziekan Wydziału Teologicznego, złożyły się wspomnienia osobiste. Były to luźniejsze wypowiedzi, które naświetlały sylwetkę ks. Jerzego Chmiela z różnych stron. Ks. prof. dr hab. Jan Dyduch (Uniwersytet Papieski Jana Pawła II w Krakowie) wspominał głównie współpracę z ks. Jerzym Chmielem, gdy pełnił on funkcję prorektora Papieskiej Akademii Teologicznej (1997-2000), zwłaszcza przy spotkaniach międzynarodowych, w czasie których jego znajomość języków obcych, w tym także łaciny, okazywała się bardzo przydatna. Ks. prof. dr hab. Tomasz Jelonek (Uniwersytet Papieski Jana Pawła II w Krakowie) podkreślił, że ks. Jerzy Chmiel kierował się zasadą pomocniczości w relacjach ze współpracownikami, będąc czy to dziekanem Wydziału Teologicznego (1985-1991), czy prezesem Polskiego Towarzystwa Teologicznego (1978-1987). Pozostawiał współpracownikom wolną rękę w wypełnianiu powierzonego im zadania. Ingerował tylko w wypadkach koniecznych, szukając wspólnie najlepszego rozwiązania. Z kolei ks. prof. dr hab. Łukasz Kamykowski (Uniwersytet Papieski Jana Pawła II w Krakowie) wspominał spotkania z ks. Jerzym 
Chmielem w czasie rekolekcji dla maturzystów, wykładów w seminarium duchownym i pracy w dziekanacie Wydziału Teologicznego. Zawsze uderzała go erudycja profesora, dzięki której wydobywał z tekstów biblijnych niespodziewane i aktualne treści, oraz szacunek dla człowieka. Pod nieobecność dr Marii Kantor (Uniwersytet Jagielloński) jej wspomnienia odczytała mgr Sylwia Wajner, doktorantka Uniwersytetu Papieskiego. Autorka podkreśliła u ks. Jerzego Chmiela dobrą znajomość języków biblijnych oraz zagadnień dotyczących Pisma Świętego i judaizmu, a także umiejętność przekazywania swojej wiedzy słuchaczom. Niezwykle owocny był również dla niej czas doktoratu pisanego pod kierunkiem profesora.

Każde wystąpienie odkrywało nowe aspekty bogatej, renesansowej osobowości ks. Jerzego Chmiela. Okazało się, że mimo przebywania z nim nie znaliśmy go za wiele. Istnieje potrzeba, aby wydobyć na światło dzienne i ocalić od zapomnienia jego dokonania na różnych polach. Ks. Waldemar Chrostowski zgłosił potrzebę zestawienia pełnej bibliografii prac ks. Jerzego Chmiela, gdyż dotychczasowe są niekompletne. Interesująca wymiana zdań przeniosła się do uczelnianej stołówki, gdzie sesja zakończyła się obiadem. 